\title{
ORIGIN AND EVOLUTION OF THE OPHIOLITIC COMPLEX OF ZDRALJICA (CENTRAL SERBIA)
}

\author{
K. Resimić-Šarić ${ }^{1,2}$, A. Koroneos ${ }^{1}$, V. Cvetković ${ }^{2}$ and K. Balogh ${ }^{3}$ \\ ${ }^{1}$ Department of Mineralogy, Petrology and Economic Geology, School of Geology, \\ Aristotle University of Thessaloniki, 54621 Thessaloniki, kristinas@mkpg.rgf.bg.ac.yu, \\ koroneos@geo.auth.gr \\ ${ }^{2}$ Faculty of Mining and Geology, Belgrade University, Đušina 7, 11000 Belgrade, Serbia and \\ Montenegro, cvladica@mkpg.rgf.bg.ac.yu \\ ${ }^{3}$ Institute for Nuclear Research ATOMKI of Hungarian Academy of Sciences, Bem ter. 18/c, 4026 \\ Debrecen, balogh@moon.atomki.hu
}

\section{ABSTRACT}

The ophiolitic complex of Ždraljica (Central Serbia) belongs to the Eastern Branch of the Vardar suture zone. It was emflaced during the Upper Jurassic. The complex consists predominately of a MORB/VAB-like tholeiitic suite, represented mostly by gabbros and diabases. Small occurrences of cummulitic peridotites, basalts and plagiogranites also appear. The tholeiitic suite is intruded by calc-alkaline intermediate and acid magmas. Geochemical data suggest that the ŽOC tholeiitic rocks originated by partial melting of a spinel-Iherzolite source. Non-modal batch melting modeling indicates 10 to $15 \%$ of partial melting of such a source. The magmas were later modified by fractional crystallization. One-step major element modeling requires $40 \%(F=0.60)$ of fractional crystallization of a mineral assemblage: $\mathrm{Pl}_{52.9} \mathrm{Cpx}_{12.5} \mathrm{Ol}_{26.1} \mathrm{Ttn}_{2.9} \mathrm{Ap}_{4.4} \mathrm{Mgt}_{1.0}$. The model is supported by the variation patterns of most trace elements.

\section{INTRODUCTION}

The Ždraljica Ophiolitic Complex (ŽOC) is situated near Kragujevac (Central Serbia), about 150 $\mathrm{km}$ south of Belgrade. Geotectonically, it belongs to the Eastern Branch of the Vardar Zone Composite Terrane - VZCT (Karamata et al. 1994, Resimić-Šarić et al. 2000), marking, with other similar occurrences, the suture zone of the Vardar ocean and boundary between the VZCT and the SerboMacedonian Massive (Fig. 1). The continuation of ophiolitic occurrences can be followed further to the south in Southern Serbia, F.Y.R. of Macedonia and Greece (e.g. Bébien 1977). Northwards, this zone continues as tie Mures ophiolites in the Apuseni Mountains in Romania (Zacher \& Lupu 1999 and references therein).

The ŽOC covers about $30 \mathrm{~km}^{2}$, representing middle and upper parts of the oceanic crust. It mostly consists of gabbros and diabases. The complex is associated with the Upper Jurassic diabase-chert formation (Marković et al. 1968, Dolić et al. 1981) and it is covered by Tithonian limestones and Lower Cretaceous paraflysch sediments as an over-step sequence (Karamata et al. 1999).

The ŽOC started to be investigated in detail few years ago and the first results and interpretation about the evolution of tholeiitic series rocks will be given in this paper. Special attention will be given to processes in the source, magma modification processes and geotectonic setting of the complex. It is argued that the tholeiitic series originated by a moderate degree of partial melting of a Iherzolitic upper mantle source. Crystal fractionation was recognized as a main process of magma modification and present major and trace element modeling. Available data suggest that the ŽOC formed in a MORB-like setting, although VA setting cannot be entirely excluded. 


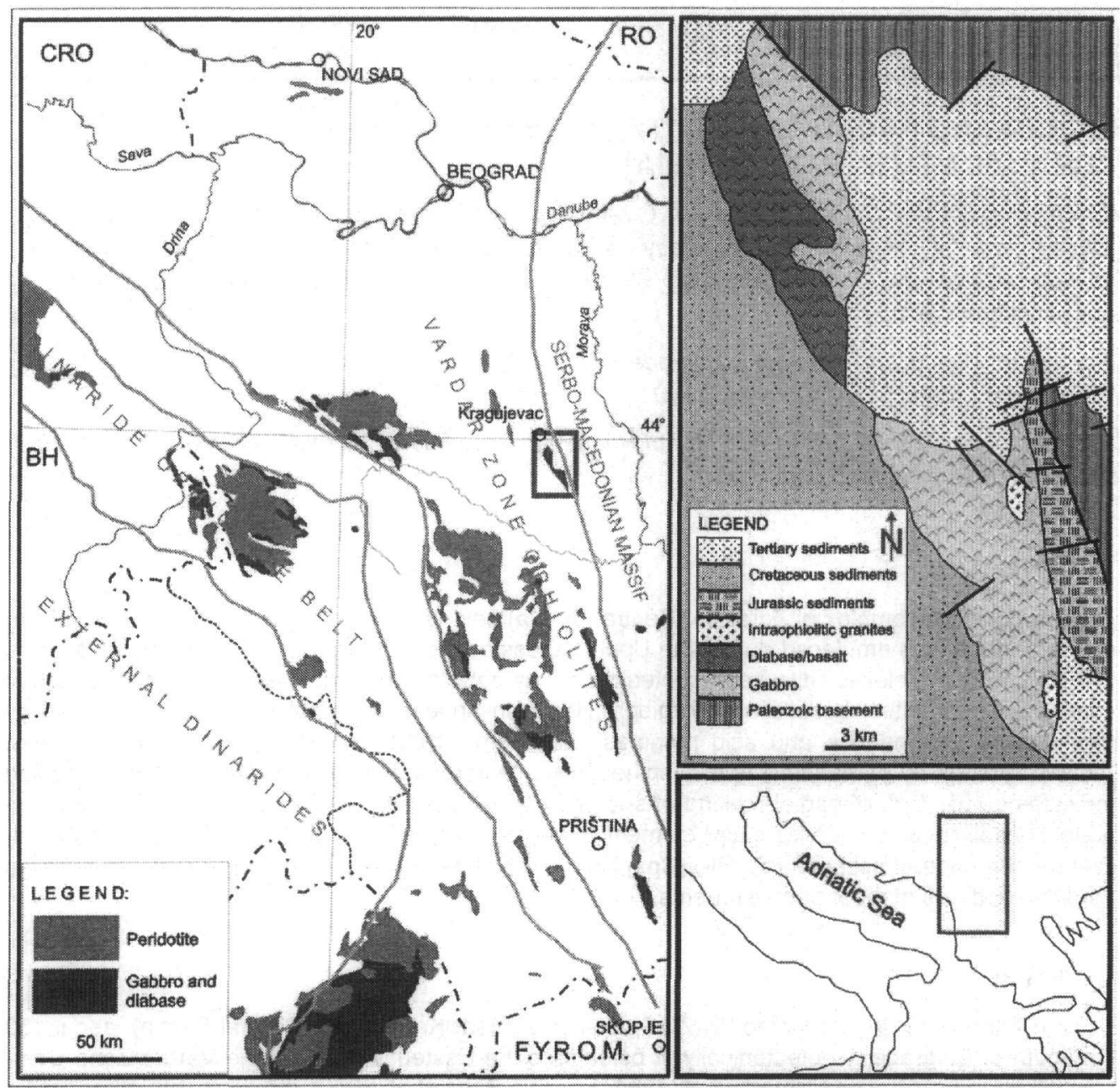

Figure 1. Geotectonic position of the Ždraljica Ophiolitic Complex (ŽOC). The terrane boundaries and distribution of Mesozoic ophiolites are from Karamata et al. (1994) and Dimitrijevic (1992). The simplified sketch (upper right) shows geology of the ŽOC after Marković et al. (1968) and Dolić et al. (1981).

\section{ANALYTICAL PROCEDURE}

Analyses of major and selected trace elements of whole rock samples were done by XRF method at the Department of Earth Sciences of the University of Perugia (Italy). The analyses have been performed using an X-ray tube completed with a $\mathrm{Rn}$ and $\mathrm{W}$ anode under conditions within a range of 40-45 mV I=30-35 mA. A LiF-200 crystal analizator and scincilating detector were used. Precision is better than $10 \%$ for $\mathrm{V}, \mathrm{Cr}, \mathrm{Ni}, \mathrm{Y}, \mathrm{Zr}$ and $\mathrm{Ba}$, and better than $5 \%$ for all the other elements. The accuracy has been tested on international standards, and is better than $10 \%$.

The mineral phases of the rocks were analyzed by Energy Dispersive Spectrometry (EDS) at the Aristotle University of Thessaloniki, Greece. Mineral phases were imaged with backscattered electrons (BSE) and quantitatively analyzed using a LINK AN 1000 EDS microanalyser attached to a JEOL JSM-840 Scanning Electron Microscope. Operating conditions were $15 \mathrm{kV}$ accelerating potential, beam current $3 \mathrm{nA}$, surface electron beam $1 \mu \mathrm{m}^{2}$ and counting time 80 seconds. The ZAF4/FLS software provided by LINK was used for corrections. Minerals (albite, orthoclase, diopside, wollastonite, olivine, periclase) and pure metals were used as standards. 
The samples were analyzed for KIAr in the Institute for Nuclear Research ATOMKI of Hungarian Academy of Sciences in Debrecen (Hungary). The ages are reported in Resimić-Šarić et al. (2002) while the analytical procedure is given in Balogh (1985).

\section{ROCK CLASSIFICATION AND PETROGRAPHY}

Igneous rocks occurring in the ŽOC are generally divided into two genetically different suites: (1) suite of a tholeiitic and (2) suite of a calc-alkaline affinity (Resimić 2000). The first suite consists of serpentinised peridotites, cummulitic and massive gabbros, diabases and plagiogranites. The second group comprises intermediate and acid rocks (quartzdiorites, quartzmonzodiorites, granodiorites and leucocratic granites), and they cut the rocks of the tholeiitic suite. This paper is focused on the tholeiitic rocks of the ŽOC. A detailed study of the calc-alkaline magmatism intruding ophiolites is in progress and t'? ese data will be published in a subsequent paper.

Generally, the rocks of the tholeiitic suite show effects of extensive alteration and low- to medium-T metamorphic processes. Therefore, they have sometimes been classified as spilites and metabasalts, or even chlorite-epidote-albite schists and serpentinites. In the following text we will present petrography and mineral chemistry of most fresh igneous rocks of the ŽOC.

Wherlites are developed in the lower part of the Ždraljica ophiolitic complex. They occur as very rare and small cummulitic pods and layers within gabbros. They display allotriomorphic and orthocummulitic texture. The main mineral phases are olivine $\left(\mathrm{FO}_{85.73}\right)$ and diopside (Mg\# 89.8$)$ and spinels as accessories.

Gabbros occur as irregular blocks or sheets of massive and cummulitic facies. They show coarse-grained, rarely fine-grained and poikilitic, coarse-grained ophitic and orthocummulitic texture. The main constituents are plagioclase (63.8-97.6\%An), sometimes albitized (3.7-19.6\%An), clinopyroxenes (diopside - Mg\# 73.0-93.3 and augite - Mg\# 62.4-86.7) and, only rarely, totally serpentinized olivine. Accessories are magnetite, sphene and apatite. Secondary minerals are epidote, uralite, chlorite, tremolite, calcite, serpentine, pyrite and rarely magnesiohornblende.

Diabases occur as single dykes or dyke-swarms intruding gabbros or as irregular massive bodies. They show ophitic, intergranular or intersertal texture, sometimes with glassy chilled margins. Plagioclase (70.2-85.7 \%An) and augite (Mg\# 61.3-80.2) are the main mineral phases, while accessories are magnetite, sphene and glass. Metamorphosed diabases are composed mostly of albite (2.3-6.9\%An), epidote/zoisite, uralite, tremolite, magnesiohornblende, calcite and pyrite.

Basalts appear as pillow lavas, primary and redeposited hyaloclastites and rarely as relicts of coherent lava flows. They show glomeroporphyritic, ophitic, aphyric and intersertal texture. Phenocrysts are ubiquitously albitized plagioclase (7.7-11.7 \%An), relicts of augite (Mg\# 60.2 and 77.7) and severely serpentinized olivine, while the groundmass is composed of chloritised glass, plagioclase microlites and opaque minerals.

Plagiogranites occur as small dyke- or sill-like intrusions and irregular bodies within diabases. They display hypidiomorphic and fine-grained granular texture. Albite and quartz are the main minerals, accessories are niagnesiohornblende, magnetite and apatite, while epidote/zoisite and chlorite are secondary products.

\section{AGE OF THE ŽOC}

Radiometric age determinations of ŽOC rocks were published in Resimić-Šarić et al. (2002) and here we shall present a brief summary. Previously, the ŽOC was mapped as a part of the diabasechert formation, the age of which has been variously determined, from Archean to Tertiary (Ćirić 1955, Gočanin 1938, Terzić 1962, Marković et al. 1968).

The presence of an Upper Jurassic over-step sequence proves that the emplacement of the ŽOC occurred before the Upper Jurassic. It is in agreement with the presumed closure of the Eastern Branch of the Vardar Zone (Karamata et al. 1999) and the emplacement of Mures ophiolites (e.g. Bortolotti et al. 2002).

$\mathrm{K} / \mathrm{Ar}$ analyses on various mineral and whole rock samples of both ŽOC tholeiitic and calc-

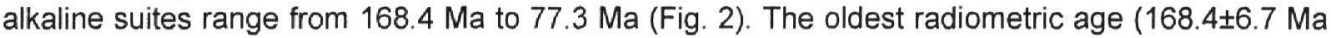
- magnesiohornblende from calc-alkaline quartzdiorite) may correspond to the crystallization age or 
a minimum age of the ŽOC ophiolite emplacement. The latter is in agreement with the age of the overstep sequence. To better constrain the significance of these radiometric ages we have to know more about the origin and evolution of the calc-alkaline granitoid rocks. On the other hand, all younger ages $(152 \pm 21-77.3 \pm 3.6 \mathrm{Ma})$ may comprise processes of ocean floor metamorphism or post-emplacement evenis.

Similar KJAr ages have been reported on the ophiolitic rocks of the Bükk Mts., N Hungary; $166 \pm$ $8 \mathrm{Ma}$ has been measured on hornblende from gabbro at Szarvaskő and muscovite from the contact of the gabbro resulted $165 \pm 5 \mathrm{Ma}$ (Árva-Sós et al. 1987). On the same muscovite an Ar/Ar plateau age of $162.9 \pm 0.9 \mathrm{Ma}$ has been published by Balogh \& Pécskay (2001). In the SE foreland of the Bükk Mts. borehole Hejöszalonta-1 reached spilitized basalt at $1650.3 \mathrm{~m}$, its age was determined with KJAr isochron method as $160.6 \pm 11.6 \mathrm{Ma}$ and 159.4 $\pm 3.2 \mathrm{Ma}$ (Balogh \& Pécskay 2001).

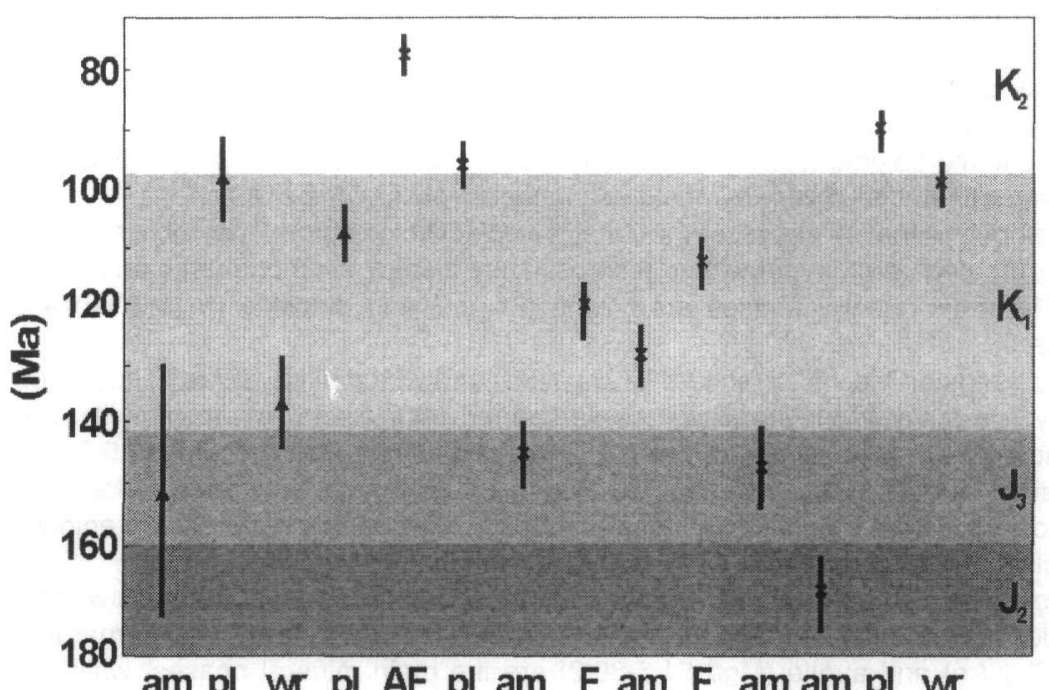

Figure 2. KJAr data for anáysed rocks of the Ždraljica ophiolitic complex (Resimić-Šarić et al. 2002). Explanation: $\mathbf{\Lambda}$ - gabbros and diabases, $\mathbf{x}$ - calc-alkaline suite; Abbreviations: am - amphibole, $\mathrm{pl}$ - plagioclase, AF alkali feldspar, $F$ - feldspars, wr - whole rock, $J_{2}$ - Middle Jurassic, $J_{3}$ - Upper Jurassic, $K_{1}$ - Lower Cretaceous, $\mathrm{K}_{2}$ - Upper Cretaceous.

\section{GEOCHEMISTRY}

Analyses of major element oxides and selected trace elements of 14 samples of basic and one sample of acid tholeiitic rocks are given in table 1.

Their $\mathrm{SiO}_{2}$ contents range from $30.82 \mathrm{wt} . \%$ to $51.31 \mathrm{wt} . \%$ while the silica content of plagiogranite is $71.57 \%$. Chemical behavior of major and trace elements is described using $\mathrm{MgO}$ as differentiation index. The contents of $\mathrm{TiO}_{2}, \mathrm{CaO}, \mathrm{FeO}_{t}$ and $\mathrm{P}_{2} \mathrm{O}_{5}$ decrease with decreasing of $\mathrm{MgO}$ concentrations. $\mathrm{SiO}_{2}$ and $\mathrm{Al}_{2} \mathrm{O}_{3}$ contents increase from the most primitive sample to the most evolved one, while contents of $\mathrm{Na}_{2} \mathrm{O}$ are rather constant. $\mathrm{K}_{2} \mathrm{O}$ contents are scattered. Concentrations of $\mathrm{V}, \mathrm{Co}, \mathrm{Cu}, \mathrm{Zn}$ and $\mathrm{Ga}$ decrease with decreasing $\mathrm{MgO}$ contents while $\mathrm{Y}$ and Nb concentrations slightly decrease. $\mathrm{Pb}$ and $\mathrm{Th}$ contents increase with some scattering, $\mathrm{Sr}, \mathrm{Ba}, \mathrm{Cr}$ and $\mathrm{Ni}$ contents are highly scattered while $\mathrm{Zr}$ and $\mathrm{Ce}$ concentracions do not show changes in their contents during the evolution.

\section{DISCUSSION}

Analyses of nine selected samples of basic rocks will be included in the discussion. The samples were screened by taking into consideration effects of alteration and metamorphism. 
The tholeiitic suite rocks of the ŽOC were plotted on a MORB-normalized (Pearce 1983) spider diagram (Fig. 3). Generally, three groups of rocks can be distinguished: (1) cummulitic gabbros, (2) primitive and evolved gabbros and diabases and (3) a plagiogranite sample.

All the basic rocks show subparallel trace element pattern with cummulitic samples having lower concetrations of most race elements. The least evolved gabbros and diabases have similar concentrations of most trace elements to MORB. N-MORB affinity of the ŽOC mafic rocks is also inffered from HFSE ratios, e.g. Zr/Y(around 2.5) and Ti/Y (around 240) (Saunders \& Turney 1984). In addition, according to $(\mathrm{Y}+\mathrm{Nb})$ vs. $\mathrm{Rb}$ and $\mathrm{Y}$ vs. $\mathrm{Nb}$ (Pearce et al. 1984) discrimination diagrams, the ŽOC plagiogranite shows an ORG affinity.

Table 1. Major (wt\%) and trace (ppm) element data of rocks of the ŽOC.

\begin{tabular}{|c|c|c|c|c|c|c|c|c|c|c|c|c|c|c|c|}
\hline \multirow{2}{*}{$\begin{array}{l}\text { Rock- } \\
\text { type } \\
\text { Sam- } \\
\text { ple }\end{array}$} & \multirow{2}{*}{\begin{tabular}{|c|}
$p$ \\
V371a \\
\end{tabular}} & \multicolumn{9}{|c|}{ g } & \multicolumn{3}{|c|}{ d } & \multirow{2}{*}{\begin{tabular}{|c|}
$b$ \\
$E 521 a$ \\
\end{tabular}} & \multirow{2}{*}{$\begin{array}{l}\text { pl-g } \\
\text { E509 }\end{array}$} \\
\hline & & V315 & 4 & M102 & $8 B$ & V367b & $2 A$ & $3 B$ & A607 & $\mathrm{A} 602$ & $8 A$ & $2 F$ & E536d & & \\
\hline $\mathrm{SiO}_{2}$ & 30.82 & 47.54 & 50.75 & 49.03 & 49.85 & 46.14 & 39.45 & 41.67 & 49.64 & 49.64 & 51.31 & 39.88 & 44.07 & 38.65 & 71.57 \\
\hline $\mathrm{TiO}_{2}$ & 0.11 & 1.03 & 0.53 & 0.86 & 0.76 & 1.05 & 1.10 & 0.92 & 0.28 & 0.62 & 1.09 & 2.21 & 1.25 & 2.23 & 0.42 \\
\hline $\mathrm{Al}_{2} \mathrm{O}_{3}$ & 3.13 & 15.37 & 15.05 & 15.76 & 15.93 & 22.26 & 8.52 & 11.44 & 15.57 & 15.75 & 14.34 & 8.16 & 14.61 & 9.41 & 12.48 \\
\hline $\mathrm{FeO}_{\mathrm{t}}$ & 16.39 & 9.63 & 11.87 & 8.76 & 9.31 & 5.04 & 17.18 & 16.13 & 7.66 & 9,85 & 10.05 & 18.74 & 12.98 & 19.16 & 5.12 \\
\hline Mno & 0.39 & 0.2 & 0.14 & 0.18 & 0.18 & 0.11 & 0.39 & 0.32 & 0.15 & 0.18 & 0.18 & 0.44 & 0.25 & 0.33 & 0.11 \\
\hline $\mathrm{MgO}$ & 34.38 & 9.71 & 8.76 & 8.90 & 8.71 & 8.98 & 8.40 & 8.06 & 11.4 & 8.21 & 8.46 & 10.63 & 9.54 & 6.92 & 0.86 \\
\hline $\mathrm{CaO}$ & 2.56 & 11.76 & 13.61 & 11.57 & 10.21 & 11.34 & 18.05 & 16.52 & 11.02 & 10.19 & 9.87 & 11.48 & 13.88 & 14.4 & 2.00 \\
\hline $\mathrm{Na}_{2} \mathrm{O}$ & 0.07 & 2.15 & 1.14 & 1.95 & 1.75 & 1.31 & 2.28 & 1.93 & 1.4 & 1.86 & 2.08 & 4.33 & 1.35 & 2.97 & 5.61 \\
\hline $\mathrm{K}_{2} \mathrm{O}$ & 0.03 & 0.12 & 0.03 & 0.11 & 0.16 & 0.08 & 1.31 & 0.84 & 0.08 & 0.12 & 0.09 & 0.72 & 0.03 & 0.15 & 0.03 \\
\hline $\mathbf{P}_{2} \mathbf{O}_{5}$ & 0.04 & 0.27 & 0.15 & 0.23 & 0.17 & 0.19 & 0.18 & 0.16 & 0.17 & 0.21 & 0.19 & 0.21 & 0.22 & 0.28 & 0.08 \\
\hline LOI & 10.37 & 1.69 & 2.08 & 2.16 & 2.75 & 4.01 & 1.90 & 0.86 & 2.23 & 2.73 & 2.03 & 1.73 & 1.08 & 3.84 & 1.19 \\
\hline v & 46 & 273 & 247 & 263 & 215 & 50 & 224 & 212 & 155 & 208 & 282 & 279 & 334 & 262 & 43 \\
\hline $\mathrm{Cr}$ & 2032 & 451 & 443 & 381 & 358 & 112 & 673 & 603 & 564 & 351 & 244 & 157 & 188 & 115 & 13 \\
\hline Co & 159 & 45 & 39 & 47 & 38 & 35 & 61 & 68 & 42 & 41 & 42 & 49 & 51 & 68 & 10 \\
\hline $\mathrm{Ni}$ & 1813 & 125 & 156 & 112 & 83 & 171 & 228 & 200 & 153 & 100 & 88 & 70 & 62 & 78 & 30 \\
\hline $\mathrm{Cu}$ & 29 & 73 & 37 & 61 & 74 & 68 & 128 & 123 & 61 & 19 & 15 & 144 & 72 & 81 & 52 \\
\hline $\mathrm{Zn}$ & 107 & 60 & 39 & 47 & 50 & 27 & 87 & 85 & 36 & 35 & 51 & 129 & 76 & 136 & 45 \\
\hline $\mathrm{Ga}$ & 4 & 18 & $1 \mathrm{~J}$ & 14 & 12 & 10 & 24 & 17 & 11 & 13 & 16 & 29 & 16 & 25 & 14 \\
\hline Rb & 1 & 1 & 1 & 1 & 1 & 1 & 24 & 19 & 3 & 1 & 1 & 6 & 1 & 1 & 2 \\
\hline $\mathrm{Sr}$ & 21 & 159 & 265 & 197 & 129 & 156 & 482 & 336 & 142 & 150 & 119 & 207 & 79 & 147 & 77 \\
\hline$Y$ & 6 & 22 & 12 & 25 & 18 & 4 & 25 & 18 & 10 & 17 & 24 & 37 & 25 & 55 & 133 \\
\hline $\mathbf{Z r}$ & 13 & 73 & 26 & 67 & 48 & 16 & 47 & 35 & 15 & 39 & 71 & 117 & 29 & 130 & 624 \\
\hline Nb & 3 & 5 & 0,1 & 6 & 3 & 0,1 & 3 & 4 & 2 & 3 & 3 & 8 & 4 & 9 & 17 \\
\hline $\mathrm{Ba}$ & 2 & 8 & 4 & 8 & 4 & 2 & 60 & 29 & 2 & 2 & 10 & 66 & 2 & 21 & 7 \\
\hline La & 0 & 4 & 6 & 4 & 6 & 3 & 13 & 16 & 5 & 7 & 0 & 6 & 13 & 20 & 10 \\
\hline $\mathrm{Pb}$ & 23 & 7 & 14 & 5 & 9 & 9 & 27 & 20 & 5 & 9 & 8 & 26 & 7 & 22 & 12 \\
\hline Ce & 3 & 3 & 2 & 3 & 2 & 3 & 2 & 2 & 3 & 3 & 2 & 2 & 3 & 3 & 89 \\
\hline Th & 6 & 0 & 1 & 1 & 3 & 3 & 11 & 1 & 2 & 0 & 3 & 5 & 1 & 7 & 4 \\
\hline
\end{tabular}

$\mathrm{FeO}_{\mathrm{t}}$ : total iron as ferrous, Abbreviations: $\mathrm{p}$ - peridotite, $\mathrm{g}$ - gabbro, $\mathrm{d}$-diabase, $\mathrm{b}$ - basalt, $\mathrm{pl}-\mathrm{g}$ - plagiogranite

\subsection{Modeling of partial melting and fractionation processes}

In order to further elaborate the source and low-pressure modification processes, major and trace element modeling was performed.

Firstly, the $\mathrm{Cr}$ vs. Y log-log diagram was used to distinguish rocks, which may represent primary mantle-derived melts from those representing magmas that underwent processes of fractionation (Fig. 4). The non-modal equilibrium (batch) melting equation was used in order to calculate the $\mathrm{Cr}$ and $Y$ concentrations for range of $0-40 \%$ melting $(F=0.0-0.4)$ of a spinel Iherzolite with modal mineralogy $\mathrm{Ol}_{57} \mathrm{Opx}_{25.5} \mathrm{Cpx}_{15} \mathrm{Sp}_{2.5}$. Computer iterations were carried out for every $1 \%$ melting-step, by recalculation of the mineralogical composition of the source, according to the method proposed by Kostopoulos \& James (1992). 


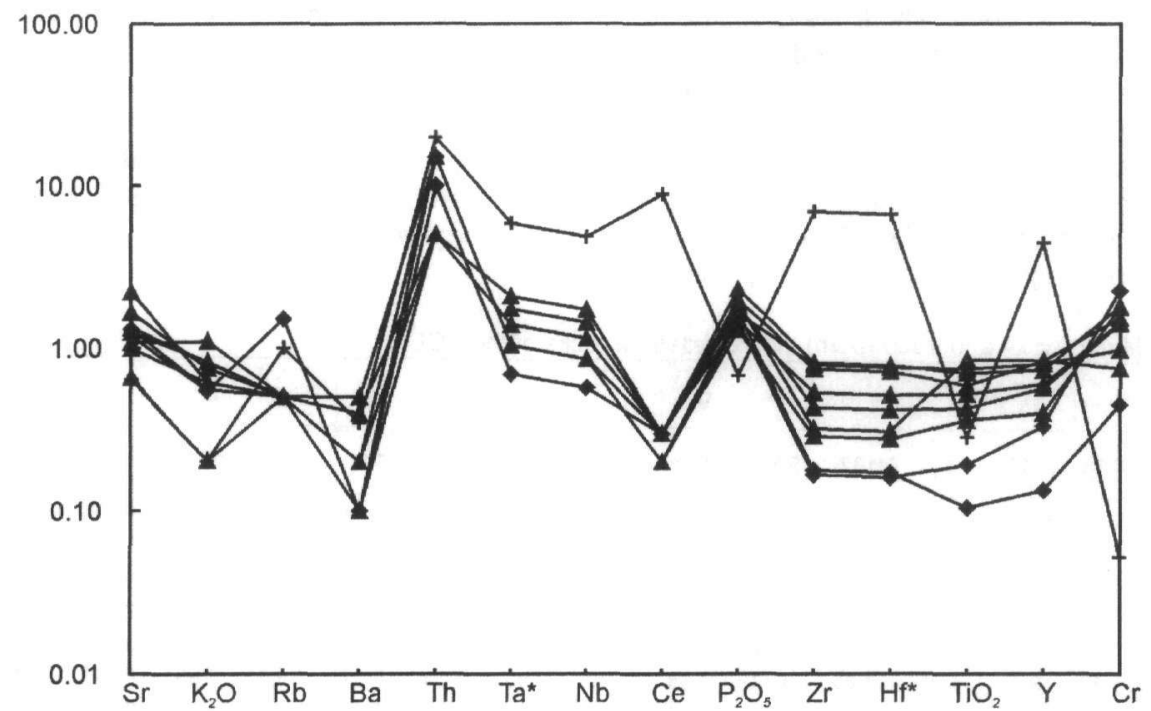

Figure 3. Spider-diagram normalized on MORB (Pearce 1983) for selected samples of the ophiolitic complex of the ŽOC. Explanation: $\mathrm{Ta}^{*}$ and $\mathrm{Hf}^{*}$ are calculated according to Rollinson (1993) $-\mathrm{Ta}^{*}=\mathrm{Nb} / 16$, and $\mathrm{Hf}^{*}=\mathrm{Zr} / 39$. ४ : cummulitic rocks, $\wedge$ : gabbros and diabases, +: plagiogranite.

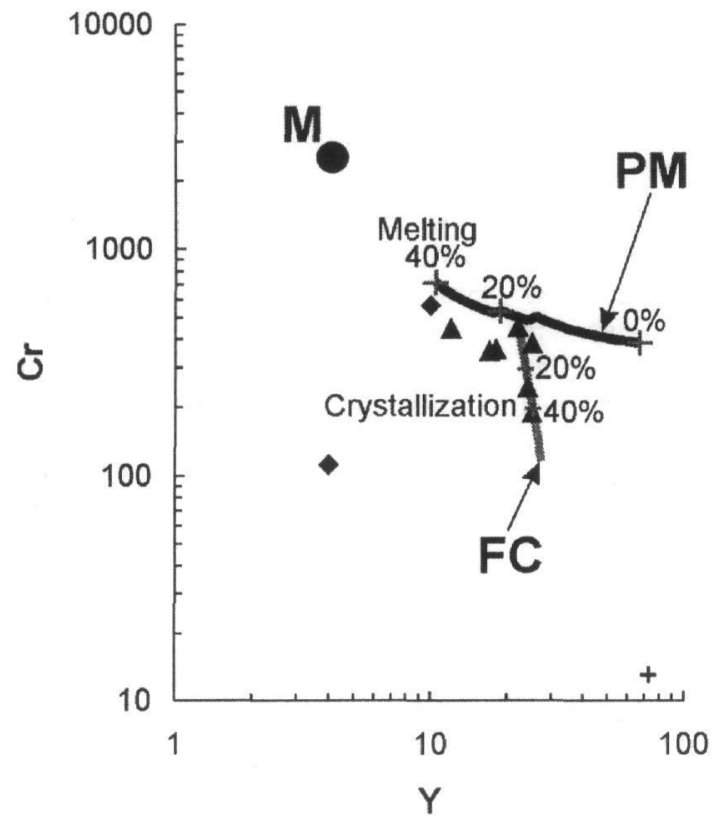

Figure 4. Partial melting model based on $\mathrm{Cr}$ and $\mathrm{Y}$ contents of the mantle source composition (M) and fractional crystallization model of a magma originated by partial melting. Line PM represents a non modal batch partial melting model within the range $\mathrm{F}=0.0$ to $0.4(0 \%-40 \%$ melting). Line FC represents a fractional crystallization model within the range $\mathrm{F}=0.0$ to $0.6(0 \%-40 \%$ crystallization). Symbols as in figure 3 .

The plot of the calculated $\mathrm{Cr}$ and $\mathrm{Y}$ concentrations along with those of the analyzed samples supports that the $\mathrm{Cr}$-riciır samples could represent primary melts after 10 to $15 \%$ mantle-partial melting. Other samples show effects of modification processes.

The presence of glomeroporphyritic texture indicates that crystal fractionation was most important for magma modification. The major element model requires $40 \%(F=0.6)$ crystallization of a presumed primary magma (gabbro V-315) resulting in a mineral assemblage of $\mathrm{Pl}_{52.9} \mathrm{Cpx}_{12.5} \mathrm{Ol}_{26.1} \mathrm{Ttn}_{2.9} \mathrm{Ap}_{4.4} \mathrm{Mgt}_{1.0}$ to reproduce the major element composition of the more evolved 
sample (diabase 8-A) (Tab. 2). Such a process explains satisfactorily the geochemical behaviour of most trace elements (Fig. 5).

Table 2. Major element modeling of the fractional crystallization process.

\begin{tabular}{|c|c|c|c|c|c|c|c|c|c|c|c|c|c|}
\hline \multirow[b]{2}{*}{ Sample } & \multicolumn{2}{|c|}{$\begin{array}{l}\text { Parental } \\
\text { magma }\end{array}$} & \multicolumn{2}{|l|}{$\begin{array}{c}\text { Evolved } \\
\text { magma }\end{array}$} & \multicolumn{7}{|c|}{ Composition of minerals crystallized } & & \\
\hline & \multicolumn{2}{|c|}{$\begin{array}{l}\text { Gabbro } \\
\text { V-315 }\end{array}$} & $\begin{array}{r}\text { Diabase } \\
8-\mathrm{A}\end{array}$ & $(\text { obs-calc })^{2}$ & \multicolumn{2}{|c|}{$\begin{array}{r}\text { PI } \quad \text { Cpx } \\
\text { V-315E-536d } \\
\end{array}$} & \multirow{2}{*}{$\begin{array}{r}\text { Fo } \\
* \\
4185\end{array}$} & $\begin{array}{r}\mathrm{Fa} \\
*\end{array}$ & \multirow{2}{*}{$\begin{array}{r}\text { Tit } \\
\text { * } \\
29.28\end{array}$} & \multicolumn{2}{|c|}{$\begin{array}{lr}A p & M t \\
& * E-536 d \\
\end{array}$} & & \\
\hline $\mathrm{SiO}_{2}$ & 48.64 & 48.87 & 52.55 & 0.05 & 49.36 & 51.73 & & 30.09 & & 0.03 & 0.00 & $F$ & $60 \%$ \\
\hline $\mathrm{TiO}_{2}$ & 1.05 & 1.18 & 1.12 & 0.02 & 0.00 & 0.70 & 0.07 & 0.00 & 38.78 & 0.06 & 3.32 & & \\
\hline $\mathrm{Al}_{2} \mathrm{O}_{3}$ & 15.73 & 15.59 & 14.69 & 0.02 & 31.59 & 1.35 & 0.00 & 0.00 & 1.67 & 0.02 & 0.53 & PI & 52.9 \\
\hline $\mathrm{FeO}_{\mathrm{t}}$ & 9.80 & 9.72 & 10.27 & 0.01 & 0.20 & 9.49 & 2.05 & 69.42 & 1.18 & 0.00 & 86.93 & Cpx & 12.6 \\
\hline $\mathrm{MnO}$ & 0.20 & 0.16 & 0.18 & 0.00 & 0.00 & 0.30 & 0.21 & 0.28 & 0.45 & 0.00 & 0.00 & Fo & 17.0 \\
\hline $\mathrm{MgO}$ & 9.94 & 9.79 & 8.66 & 0.02 & 0.06 & 14.27 & 56.17 & 0.91 & 0.21 & 0.00 & 0.00 & $\mathrm{Fa}$ & 9.1 \\
\hline $\mathrm{CaO}$ & 12.03 & 11.68 & 10.11 & 0.13 & 14.85 & 21.50 & 0.00 & 0.08 & 28.25 & 59.58 & 0.00 & Tit & 2.9 \\
\hline $\mathrm{Na}_{2} \mathrm{O}$ & 2.20 & 2.09 & 2.13 & 0.01 & 3.72 & 0.46 & 0.00 & 0.00 & 0.13 & 0.00 & 0.00 & $A p$ & 4.4 \\
\hline $\mathrm{K}_{2} \mathrm{O}$ & 0.12 & 0.06 & 0.09 & 0.00 & 0.03 & 0.00 & 0.00 & 0.00 & 0.05 & 0.20 & 0.00 & Mt & 1.0 \\
\hline $\mathrm{P}_{2} \mathrm{O}_{5}$ & 0.28 & 0.83 & 0.19 & 0.30 & 0.00 & 0.00 & 0.00 & 0.00 & 0.00 & 40.10 & 0.00 & & \\
\hline & & & & & & & & & & & & & \\
\hline
\end{tabular}

* from Deer et al. (1992).
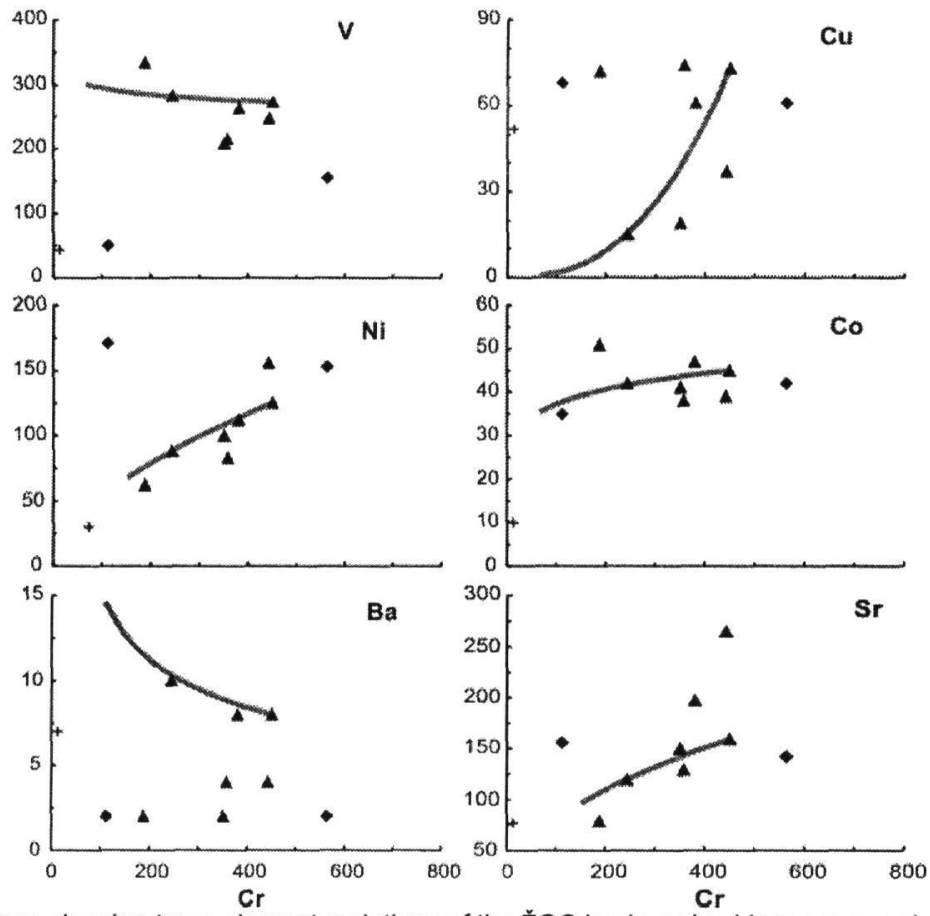

Figure 5. Diagrams showing trace element variations of the ŽOC basic rocks. Lines represent a fractional crystallization model within the range $\mathrm{F}=0.0$ to $0.6(0 \%-40 \%$ crystallization) of an assemblage $\mathrm{Pl}_{52.9} \mathrm{Cpx}_{12.5} \mathrm{Ol}_{26.1} \operatorname{Ttn}_{2.9} \mathrm{Ap}_{4.4} \mathrm{Mgt}_{1.0}$ using partition coefficients from the literature. Symbols as in figure 3 . 


\subsection{Geotectonic setting}

The available analytical data at the moment cannot provide an unambiguous answer about geotectonic setting of the ŽOC. Analysed gabbro and diabase samples, which have been plotted on $\mathrm{Nb}^{\star 2}$-Zr/4-Y (Meshede 1986) and V vs. Ti (Shervais 1982) diagrams occupy both MORB and VAB fields. The same is contirmed by chemical compositions of clinopyroxenes plotted on the $\mathrm{Ti}+\mathrm{Cr}$ vs. Ca (Letterier at al. 1982) and $F_{1}$ vs. $F_{2}$ (Nisbet \& Pearce 1977). More precise data could be expected in future, after analyzing REE contents and isotope composition of the ŽOC rocks.
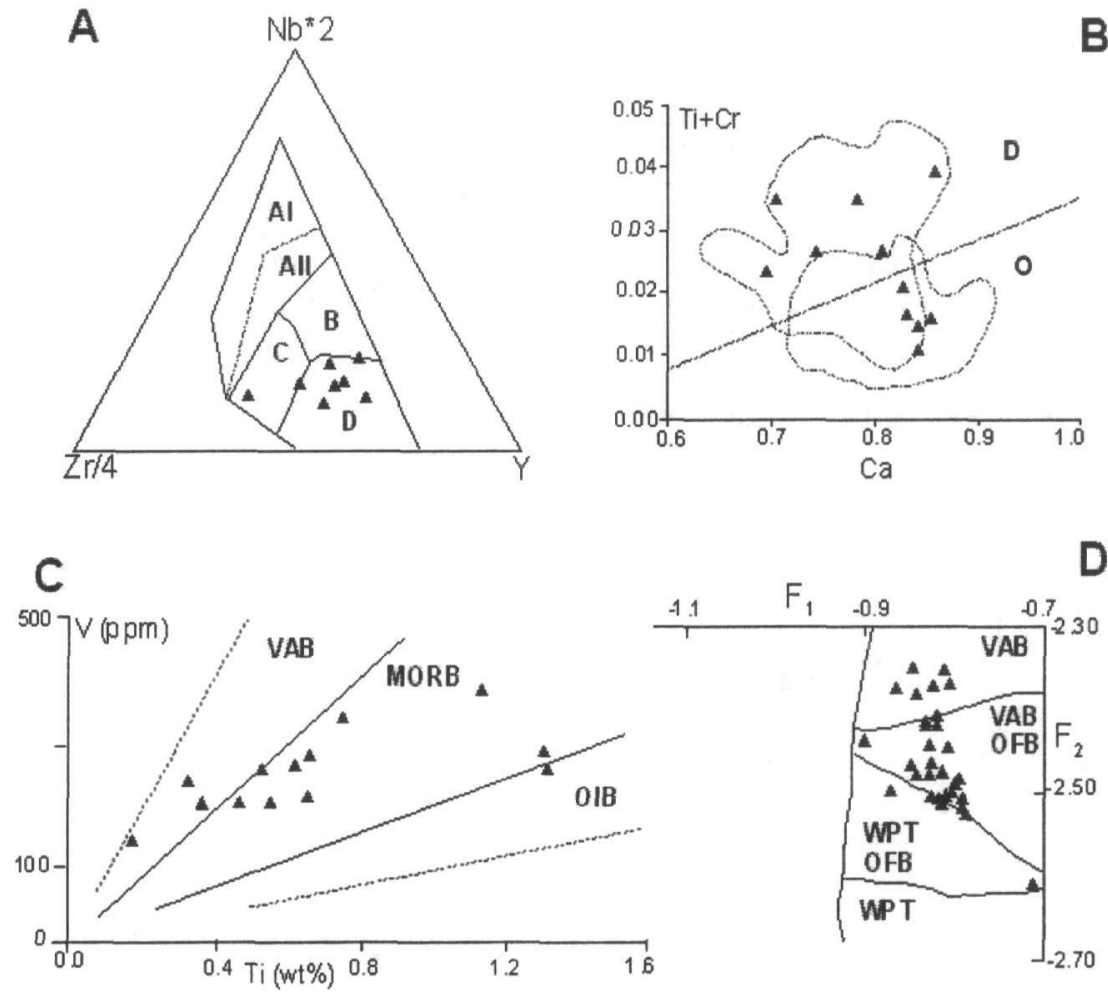

Figure 6. Diagrams for analyzed rocks (a-c) and clinopyroxenes (b-d) showing the geotectonic setting of the ŽOC. A. Nb`2-Zr/4-Y (Meshede 1986). Al: within-plate alkali basalts, All, within-plate alkali basalts and withinplate tholeiites, B: E-type MORB, C: within-plate tholeiites and volcanic-arc basalts, D: $\mathrm{N}$ - type MORB and volcanic-arc basalts. B. Ti+Cr vs. Ca (Letterier et al. 1982). D: field of MORB and other tholeiites from a spreading zone, O: volcanic arc hasalts. C. V vs. Ti (Shervais 1982). VAB: volcanic arc basalts, MORB: mid-ocean ridge basalts, OIB: ocean island basalts. D. $F_{1}$ vs. $F_{2}$ (Nisbet \& Pearce 1977). VAB: volcanic arc basalts, OFB: ocean floor basalts, WPT: within-plate tholeiites. $\mathbf{A}$ : diabases and gabbros

\section{SUMMARY}

The ophiolitic complex of Ždraljica belongs to the Eastern Branch of the Vardar Zone Composite Terrane. It is composed mostly of gabbros and diabases with small occurrences of serpentinised wherlites, basalts and plagiogranites. This tholeitic suite of rocks is intruded by intermediate and acid magmas of calc-alkaline character.

The emplacement of the ŽOC was before Upper Jurassic. Available KJAr data gave a probable age of crystallization of about $168 \mathrm{Ma}$. The time of different metamorphic events are also recorded.

The tholeiitic magmas of the ŽOC may have been formed by partial melting of the spinelIherzolite $\left(\mathrm{Ol}_{57} \mathrm{Opx}_{25.5} \mathrm{Cpx}_{15} \mathrm{Sp}_{2.5}\right)$ source. The results of a non-modal batch melting imply that the most primitive samples of the ŻOC have similar composition to melts formed by $10-15 \%$ of partial 
melting of such a source. More evolved magmas are modified by fractional crystallization $(F=0.6)$ with the following fractionating assemblage: $\mathrm{Pl}_{52.9} \mathrm{Cpx}_{12.5} \mathrm{Ol}_{26.1} \mathrm{Ttn}_{2.9} \mathrm{Ap}_{4.4} \mathrm{Mgt}_{1.0}$.

Geochemical characteristics show that tholeiitic magmas have a MORB and VA affinity. Therefore, determination of a geotectonic setting cannot be done precisely.

\section{ACKNOWLEDGMENT}

This study was supported by Serbian Academy of Sciences and Arts (Project "Geodynamics"), Ministry of Sciences, Technology and Development of Serbian Government, Ministry of Sciences and Environment (Project No. 1767) as well as Hungarian Science Fund No. T029897.

The authors thank to Prof. Dr Giampiero Poli (Department of Earth Sciences, University of Perugia) for providing XRF analyses and Dr Eleni Pavlidou (Department of Physics, Aristotle University of Thessaloniki), who analysed chemical composition of minerals.

\section{REFERENCES}

Árva-Sós E., Balogh K., Ravasz-Baranyai L. \& Ravasz Cs. 1987. KJAr dates of Mesozoic igneous rocks in some areas of Hungary. Ann. Rep. of Hung. Geol. Inst. on 1985, 295-307 (in Hungarian with English abstract).

Balogh K. 1985. KJAr dating of Neogene volcanic activity in Hungary: experimental technique, expiriences and methods of chronological studies. ATOMKI report, D/1, 277-288.

Balogh K. \& Pécskay Z. 2001. K/Ar and Ar/Ar geochronological studies in the Pannonian-Carpathians-Dinarides (PANCARDI) region. Acta Geol. Hung., 44/2-3, 281-299.

Bébien J., 1977. Mafic and ultramafic rocks associated with granites in the Vardar zone. Nature, 270, 232-234.

Bortolotti V., Marroni M., Nicolae I., Pandolfi L., Principi G. \& Saccani E. 2002. Geodynamic Implications of Jurassic Ophiolites Associated with Island-Arc Volcanics, South Apuseni Mountains, Western Romania. International Geology Review, 44, 10, 938-955.

Ćirić B., 1955. Some observations about diabase-chert formation of Dinarides. Vesnik Zav. za geol. i geofiz. istraž. N.R. Srbije. XI, 31-88.

Deer W.A., Howie R.A. \& Zussman J. 1992. An introduction to the rock-forming minerals. Longman Scientific \& Technical, 696p.

Dimitrijević M.D. 1992. Geological atlas of Serbia, 1:2.000.000. Republic foundation of geological investigations and Geological Survey Gemini.

Dolić D., Kalenić M., Markcvić D., Dimitrijević M., Radojčić R. \& Lončarević Č. 1981. Explanatory book for sheet Paracin, Basic Geological Map 1:100.000. Federal Geological Survey, Belgrade. 54pp.

Gočanin M., 1938. Tectonic characteristics of the Vardar Zone. Referati VI savetovanja geologa Jugoslavije, Ohrid, I, 475-481.

Karamata S., Dimitrijević M.N. \& Dimitrijević M.D. 1999. Oceanic realms in the central part of the Balkan Peninsula during Mesozoic. Slovak Geol. Magazine, 5,3, 173-177.

Karamata S., Knežević V., Memović E. \& Popević A. 1994. The evolution of the northern part of the Vardar zone in Mesozoic. Bull. of the Geol. Soc. of Greece. Proceeding of the $7^{\text {th }}$ Congress. Thessaloniki, May 1994, $X X X / 2,479-486$.

Kostopoulos D. \& James S., 1992. Parametrization of the melting regime of the shallow upper mantle and the effects of variable litho; pheric stretching on madle modal stratification and trace-element concentrations in magmas. Journal of Petrology, 33,3, 665-691.

Letterier J., Maury R.C., Thonon P., Girard D. \& Marchal M. 1982. Clinopyroxene composition as a method of identification of the magmatic affinities of paleo-volcanic series. Earth Planet. Sci. Lett., 59, 139-154.

Marković B., Uroševic M., Pavlović Z., Terzin V., Jovanović Ž., Karović Ž., Vujsić T., Antonijević R., Malešević M. \& Rakić M. 1968. Explanatory book for sheet Kraljevo, Basic Geological Map 1:100.000. Federal Geological Survey, Belgrade. 63pp.

Meshede M. 1986. A method of discriminating between different types of mid-ocean ridge basalts and continental tholeiites with the Nb-Zr-Y diagrams. Chem. Geol., 56, 207-218.

Nisbet E.G. \& Pearce J.A. 1977. Clinopyroxene Composition in Mafic Lavas from Different Tectonic Setting. Contrib. Mineral. Petrol., 63, 149-160.

Pearce J.A., 1983. Role of sub-continental lithosphere in magma genesis at active continental margins. In: Continental basalts and xenoliths. Hawkesworth C.J. \& Norry M.J. eds, Shiva, Nantwich, 230-249.

Pearce J.A., Harris N.B.W. \& Tindle A.G. 1984. Trace Element Discrimination Diagrams for the Tectonic interpretation of Granitic Rocks. Journal of Petrology, 24,4, 956-983. 
Resimić K., 2000. Petrology of igneous rocks of diabase-chert formation near Ždraljica (Kragujevac). Master thesis, Faculty of Mining and Geology, University of Belgrade, 169pp (in Serbian with English abstract).

Resimić-Šarić K., Balogh K. \& Cvetković V. 2002. Petrochemistry and age of the Ždraljica ophiolitic complex (Serbia). XVII Congress Of Carpathian-Balkan Geological Association, 1-4.9.2002. Bratislava. Geologica Carpatica, spec. iss., CD version, 53, index R, 1-6.

Resimić-Šarić K., Karamata S., Popević A. \& Balogh K. 2000. The eastern branch of the Vardar zone - the scar of the Main Vardar ocean. In: Geology and Metallogeny of the Dinarides and the Vardar zone. Karamata S. \& Jankovic S. eds, The Academy of Sciences and Arts of the Republic of Srpska, Banja Luka-Serbian Sarajevo, 81-85.

Rollinson H. 1993. Using Geochemical Data: Evaluation, Presentation, Interpretation. Longman Group UK Ltd., Oxford, 352p.

Saunders A.D. \& Tarney J. 1984. Geochemical characteristics of basaltic volcanism within back-arc basin. In: Marginal basin geology: volcanic associated sedimnetary and tectonic processes in modern and ancient marginal basins. Kokelaar B.P. \& Howells M.F. eds, Geol. Soc. London, 16, 59-76.

Shervais J.W. 1982. Ti-V plots and the petrogenesis of modern and ophiolitic lavas. Earth Planet. Sci. Lett., 59, $101-118$.

Terzić M. 1962. Characteristics of Serbian basic rocks. Glasnik Prir. muzeja, A,16-17, 127-137.

Zacher W. \& Lupu M. 1999. Pitfalls on the race for an ultimate Tethys model. Int. Journ. Earth Sciences, 88, $111-115$. 